\title{
Determination of User's Need and Comfort in Designing and Purchasing Green Buildings in Kano State, Nigeria
}

\author{
By Mukhtar Sabiu Yahuza², Çilen Erçin ${ }^{1 *}$
}

\begin{abstract}
Green building is the modern method adopted to attain global sustainability through individual house level. The user's demand for housing is increasing every day, also the demand for other house utility increases. These demands may include energy and water supply, refuse management, provision of new infrastructures etc. most of these demands are necessary for every user to survive. Therefore, most users engage in afforestation, increases carbon emission and rise in the Greenhouse gases level production to meet up with their demands, these activities causes' disasters to our planet. Therefore users need and green approach to sustainability are two opposite factors. This paper examines the user's need and comfort in designing or purchasing green buildings in Kano state, Nigeria. Relevant kinds of literature were revised in this work with the addition of a case study which was analysed using the descriptive approach method. A case study was picked in Kano state, Gwale Yan-Alawa quarters as an example of green building, which was analysed and rated using BREEAM and LEED assessment criteria. The result shows about $80 \%$ of user satisfaction was recorded. Also, the demand for green building keeps increasing in Kano state, which adds value to it.
\end{abstract}

Keywords: Green building, users' need, users' demand, users' perception, sustainability and green construction

\section{Introduction}

'User needs' are specific service requirements given by a client or a user to satisfy their comfort, choice, culture and religious beliefs and building aesthetics in building construction design. According to Martell et al., 2019 energy-efficiency and user's comfort are two opposite terms, hence multiobjective optimization approach can be used in resolving this issue. More than $40 \%$ of the total world's energy is utilized by buildings worldwide (UNEP \& SCBI); this consequence bring about excessive pressure on both public energy supply, nature and multiple environmental problems starting with air pollution (e.g. greenhouse gas emissions), land degradation and water pollution etc., causing depletion of the ozone layer and multiple sustainable problems. These issues can be reduced when buildings were depending on renewable sources called green sustainable buildings. The building design for needs of the users is enjoyed by the users and transforming it to be more functional and useful, assist many people in choosing the better option to their taste, so as to attain their intended policy, living style and standards (UKKorea Green Building Forum). Research shows that user's need, behaviour and awareness affects their choices of temperature, ventilation and heating, which can also affect their demand for energy without causing much physical influence to buildings. There are many methods to determine the features associated with the architectural design to attain a user's

\footnotetext{
| ${ }^{1}$ Department of Architecture, Faculty of Architecture, Near East University, Nicosia, Turkish Republic of Northern Cyprus. ${ }^{*}$ Corresponding Author

${ }^{2}$ Department of Architecture, Faculty of Architecture, Near East University, Nicosia, Turkish Republic of Northern Cyprus
} 
need and comfort in buildings. Also while energy efficiency is user-driven signifies an essential resource aimed at nurturing minimal energy need and minimal invasive interferences in buildings, there are no assurances to attain the energy level planned effectively without considering the behaviour of the users, besides the definite process of energy-performance of the green building. Though, residents and users must perform a significant task in making decisions in the method, since the comfort in green building is depending on its users. (Berg et al., 2017; Carlucci et al., 2015; Lee et al., 2016). Awkwardly, these methods are not sufficient in solving the existing problems in users need and comfort in building design. However, these methods dynamically modify building behaviours and appearances through different individual's choices of buildings based on their personalities; it also involves manipulative ideal set of points given to some specific objectives. Additionally, these strategies are potentially implemented in both existing buildings and newly-constructed ones. Research reports that workers remarks green buildings environment as conducive when compared with other modern buildings, even though, so many differences cannot be observed between those organization's employees. Eco-friendly characteristics are regularly seen amongst employees of the green building compared to employees of conventional buildings, awarding good connection to the ranking other buildings attributes (Martell et al., 2019; Sant'Anna et al., 2018).

\subsection{Aim}

This research aims at determining the user's need and comfort in designing green buildings around Kano state. Concerning this, the research will help architects in determining their client's briefings in the provision of a conducive green building environment while considering their choices.

\subsection{Material and Methodology}

Relevant papers related to users need and perception in green building design was reviewed in this research which some was listed in Table 1, in order to create a relationship between the terms green building and user need. The concept of green building was also revised here because of the significance of it in this study. A case study was chosen and analysed using descriptive analysis approach where conclusion and recommendation was drawn from it.

Table 1: Reviewed Papers (Author, 2020)

\section{S/N AUTHOR}

1) Ornetzeder et al.,

2) Smith et al.,

3) Darses et al.,

4) Leaman et al.,

5) Berg et al.,

6) Sezgin Kaya

7) Reim et al.,

8) Khorram et al.,

9) Carlucci et al.,

10) Kathia Ibacache

11) Thyssen et al.,

\section{YEAR JOURNAL}

2016 Energy and Buildings

1998 Engineering, Construction and Architectural Management

2006 Applied Ergonomics

2007 Building Research and Information

2017 Journal of Cultural Heritage

2004 Facilities

2017 Energy Procedia

2019 Energy Reports

2015 Renewable and Sustainable Energy Reviews

2020 Collection Management

2010 Architectural Engineering and Design Management 
S/N AUTHOR

12) Ahmadi-Karvigh et al.,

13) Lourenço et al.,

14) Brown et al.,

15) Mansour \& Radford

\section{YEAR JOURNAL}

2019 Energy and Buildings

2019 Journal of Cleaner Production

2010 Facilities

2014 16th Annual Architectural Research Symposium, Finland

\section{Green Building Concept}

\subsection{Emergence and Development of Green Building Concept}

The early green building standards recognized as (BREEAM) "Building Research Establishment Environmental Assessment Method" which were announced in the United Kingdom in 1990 (BRE, 2007). Subsequently, the figure of green building regulations keeps growing rapidly around the world, reaching to about 23 countries in 17 years (WGBC, 2007). Environmental sustainability factors were the numerous tools used by organizations to effectively mobilize green building regulations which are progressively understood as a vital factor to the effective application of green approaches and resolving environmental problems. The green building concept is evolving together with the wider knowledge and publications relating to the development of sustainability and it is recognised as a distinct field of learning in the past years. Modern literature connects green building concept to numerous aspects of environmental management and entire environmental performance around Pacific Asian Despite this contemporary knowledge and research, the foundations of green building theories, its dimension, the features that establish it, and how and when it affects users' needs remain unknown. (Li, Huang, Liu, \& Cai, 2011; O’Donohue \& Torugsa, 2016; Paillé, Chen, Boiral, \& Jin, 2014; Subramanian, N., Abdulrahman, Wu, \& Nath, 2016)

The rapid-growth and uncertain nature of greenhouse buildings are unexclusive in Africa. However in Nigeria green building exists yet awareness of it is lacking, so also enabling environment and economic condition, like legislation and government policies that hold back green building development in Nigeria. Hence, there are negligible incentives for potential patrons to buy or build a green building. The Nigerian currency depreciation likewise attracts poor economic situation and such causes building materials shortages, construction problems and poor building standards, leading to the usage of materials that are substandard during the construction period. This is against sustainability, and it results in many catastrophic events, like building collapse in Nigeria. The introduction of promulgated National Housing Policy (NHP, 1991) by the Nigerian government, intended to reduce the problems of housing by a legal framework provision to achieve a National Housing Scheme (NHS). NHP can attain housing goals when it suggests a promising solution to housing problems. Among the issues housing shortage in Nigeria were extraordinary urbanization rate within the metropolitan cities, poverty, the price hike of building materials etc. thus, makes only the wealthy enjoys the NHP in Nigerian. (Festus et al., 2015; Olotuah et al., 2018; Dahiru et al., 2018; Dahiru et al., 2018; Kabir, 2004).

First City Monument Bank (FCMB Group Plc.) Capital Markets Limited, is the investment banking subsidiary in Nigeria, who invested sixty-five million dollars $(\$ 65,000,000.00)$ to green construction of "Heritage Place", one of the $1^{\text {st }}$ green building in Nigeria, looking forward to linking the space of conducive office atmosphere in Lagos state, one of the 
biggest commercial centres in Nigeria. "Particularly and proudly accompanying the construction with the principles of environmental sustainability and accepts advanced technologies to achieve environmental expectations today and in the future also", said in the company's speech. This building (Heritage Place), happens to be the $1^{\text {st }}$ green commercial structure to attain the goals of Leadership in Energy \& Environmental Design (LEED) endorsement in both construction and design in Nigeria. The building has 14 floors in number, occupying about $15,730 \mathrm{~m}^{2}$ to accommodate offices with adequate car parking area, coffee/café shop, a plaza, and conference rooms. There were great possibilities of the building to attain $30-40 \%$ energy saving as compared to other conventional buildings around Lagos state. The features incorporated in this building construction are mainly environmental-friendly methods, which were implemented during the construction process of the complex, these features are re-use and recycling of waste and water, the implementation of automatic high lighting efficiency and detectors, high efficient external thermal envelope and glazing using sunshades and proper orientation of the building to utilize natural ventilation and light. The green eco-friendly building is located some minutes apart from Victoria Island which is the Central Business District (CBD) in Lagos. Other sponsors of the project were First Concept and Properties Limited (FCP), a Nigerian Special Purpose Vehicle (SPV) which was led by a private equity investor called ACTIS in Sub-Saharan Africa (Sotunde, 2014).

\subsubsection{Green Building Concept}

The concept of green building began with the concept of sustainability which 1st listed as collective practise as drawn by the Brundtland Report of the United Nation, commonly recognised as Common Future. Sustainability is regarded as development that does not hinder the needs of tomorrow while meeting the present needs (World Commission on Environment and Development, 1987: 41). The sustainable development concept is different from the traditional method of approach to development by concurrent integration, considering social inclusion, environmental protection and economic development (Connelly \& Smith, 2012). Concerning the features related to sustainable development, the natures in an environment are attached to community's activities to the extent that it took the shape of the artificial environment (Dubois \& Dubois, 2012). Congruently, the contemporary environmental drivers, succeeded around the 1960s to 1970s era, exposes the environment to detrimental human exploitation. The communal cognizance and anxieties towards the possible harmful environmental activities increased brought about the establishment of modern institutes, which brought different methods to business management and bring fresh support activities through economic, social and political fields. This gradually led to a broad collection of rules to minimize these harmful environmental activities that were noticeable consequences of rapid global warming (Bansal \& Hunter, 2003).

The existing green building conceptualizations is subjected to 2 schools of thought. Taylor et al., (2012) stated theories that green building brings a double role in a sustainable environment. Firstly, users need has direct effects on the environmental-driven variations and the green building concept is therefore frequently regarded as a human need phase of environmental management. The actual and most important conceptualization founded during the oldest scholars contributions connecting the two fields of green building and 
users demands studies shows this opinion emphasises mainly on comprehending the possible benefits and adoption of 1 or multiple definite users need practices to struggle toward refining the performance their environment. However, training, performance development and management, compensation and recruitment were among the ones investigated widely in the field of users need purposes in the green building publications (Jabbour \& Jabbour, 2016; Jabbour \& Santos, 2010; Renwick, Redman, \& Maguire, 2013; Wehrmeyer, 1996).

Going through the $2^{\text {nd }}$ school of thought which broaden the domain of the concept by identifying that green building similarly aimed at operating to promote users' behavioural and attitudinal modifications, improving the green building's ecological performance. With regard to this school of thought, a group of scholars emerges to take a broad opinion of green building to include both collective and individual user need capabilities that cause green behaviour, motivation and commitment. Congruently, scholars began to broaden their study view above exclusively user needs and instead examine wider employment features applicable to the realization of environmental benefits. Possibly. Consoli et al., (2016) discovered transformation in the social activities that affect the environmental application and establish the fact that green buildings users have higher levels of interpersonal and cognitive skills regularly in comparison to non-green buildings. The green concept teams arose to explain the team's aim which was formed (involuntarily or voluntarily) to resolve issues related to environment and enhance the performance of the environment (Ehnert, 2009; Guerci \& Carollo, 2016; Jabbour \& Santos, 2010; O’Donohue \& Torugsa, 2016).

\subsection{Green Building Description}

Green building simply means any shelter that in its operation, design or construction process minimises or eradicates the undesirable environmental effects, and provides optimistic sustainable effects to the natural environment and climate. Green buildings maintain valuable natural environmental resources and also enhance the quality of human life. The following are green building features:

- Any design which allows adaptation to environmental change;

- Renewable energy sources, e.g. wind, solar, hydro, and bioenergy;

- Use of eco-friendly materials that are not harmful, sustainable and ethical;

- Enough environmental air quality in both indoor and outdoor;

- Environmental consideration during construction, operation and design of the building;

- Minimal use of water, energy and other basic consumables;

- Minimise environmental pollution and waste produced through the process of recycling and re-use;

- Considering the quality of users' comfort in designing, constructing and operating the building.

However, any shelter can be regarded as green building regardless of its type or use, provided it has any of the factors mentioned above. In this regard it is clear that green buildings around the world differ due to differences in country's or region's climatic conditions or certain physical, social, cultural, economic, traditional, wide-range of environment or various building types and ages, social priorities and religious beliefs; 
Altogether these factors form a magnanimous approach to the green building construction differences in a country (WorldGBC, 2020).

\subsection{Study Area}

The people surrounding villages in Kano state mostly practice subsistence farming. Kano is the most populated state among the 36 states in Nigeria (refer to table 2). Economically, Kano is the Centre of Commerce in Nigeria, because of high commercial activities that were carried out the state. Sudan Savannah is the vegetation found in Kano state with sings of Guinea Savannah found in the southern region of the state along the boundary with Kaduna and Bauchi states (Iloeje, 2001). The eastern and northern region of the state is Sudan savannah. Kano is located in the north-western region of Nigeria, created on May 27, 1967, by former Military Head of State Yakubu Gowon. Kano state also shares boundaries with Bauchi State to the south-east, Jigawa State to the north-east and Katsina State to the north-west.

Table 2: Population Figures of Kano State (Census, 2006; Mortimore, 1989; World Bank, 2017 and United Nation, 2019)

\begin{tabular}{|c|l|l|}
\hline $\mathrm{s} / \mathrm{n}$ & Parameter & FIGURE \\
\hline 1 & Density & 470 People $/ \mathrm{km} 2$ \\
\hline 2 & Coordinates & $11^{\circ} 30^{\prime} 00^{\prime} \mathrm{N} 08^{\circ} 30^{\prime} 00^{\prime \prime} \mathrm{E}$ \\
\hline 3 & Climate/Vegetation & Sudan Savannah \\
\hline 4 & Duration of Rainfall & April-October \\
\hline 5 & Maximum Temperature & 35 to $40^{\circ} \mathrm{C}$ \\
\hline 6 & Total land coverage & $20,131 \mathrm{~km} 2(7,773 \mathrm{mi} 2)$ \\
\hline
\end{tabular}

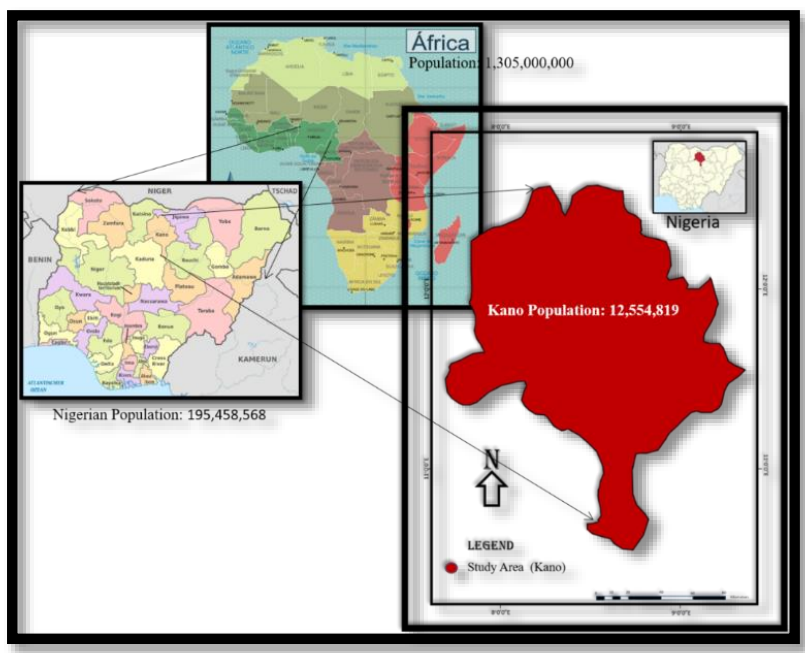

Fig.1: Study Area and Population (Census, 2006)

In fig. 1 a map of Kano state and its location in Nigeria is presented, Kano is located in the north-western part of the country, having 44 local government areas makes among the interesting states across the country. As shown in the fig. 1 it has 12554,819 population as stated in the census, 2006. This shows the need for renewable energy in Nigeria to enhance 
the livelihood of the indoor environment within domestic, industrial, commercial and office buildings.

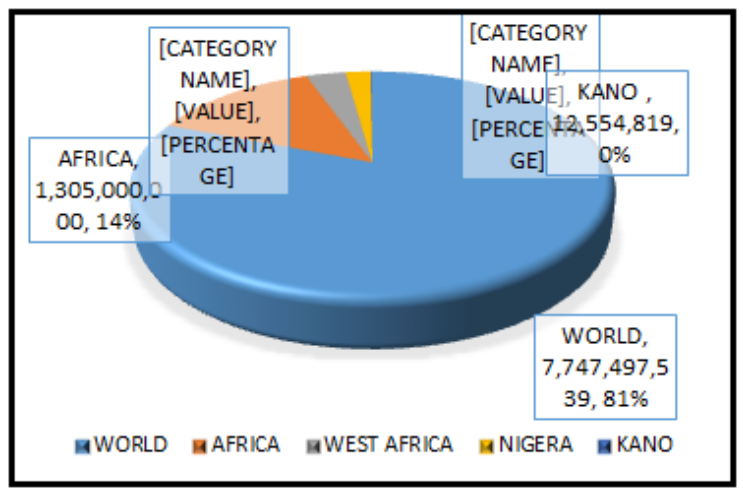

Fig. 2: 2016 Summary of the Population Figures (Census, 2006)

This pie chart presented above (fig.2) presents the world's population, African and west African population and later went forward to explain the population of Nigeria and Kano state while giving the percentage of each. Nigeria alone carries $2 \%$ of the total world's population (in 2006), however in fig. 3 Kano has $6 \%$ of the total population of Nigeria out of 36 states without the capital city Abuja, which makes it the most important region in Nigeria has been the highest in population.

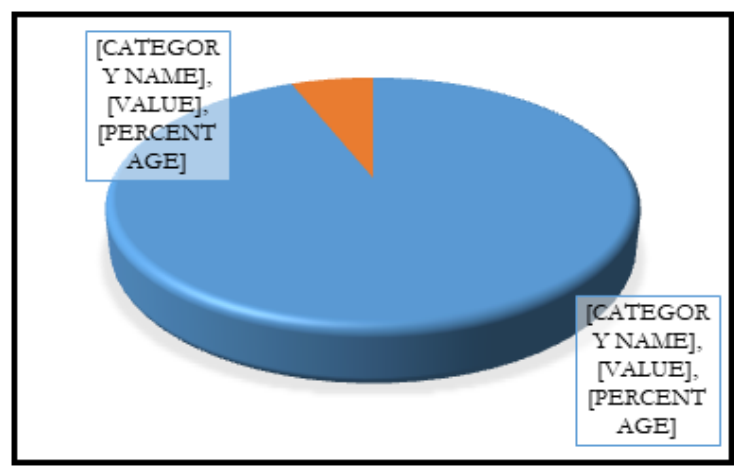

Fig.3: Projected Population Figures of Kano in comparison with the Nigerian population in 2019 (Author)

\section{Design Criteria and User Requirements in Green Buildings}

\subsection{Relationship between Users Need and Architects}

In building designs, architects do not have much personal inputs against their customers' needs or without considering the end-users, though during the transformation of the users' idea architects also apply their experiences, considers local regulations and formal knowledge (Darses \& Wolff, 2006). This statement by Darses et al., 2006 entails the relationship between architect and customers, here, it means that customer is always right and his demands on the end-product should not go against his wish. However, in 
trying to solve the problem in building design the end-users' needs and comfort should be considered, while also putting in mind other design regulations, standards, talent and formal training. The study of applied science in material construction aimed at yielding productivity and comfort by minimizing user's discomfort and health-related problems attached with the design is regarded as ergonomic, and scientists that study such aspects are called ergonomist. Also called biotechnology, human engineering, human factors engineering. While users or clients are those people who utilize the design produced by the ergonomist.

\subsection{Determination of User's Need in Green Building}

Architects have the problems of misinterpretation of users need in green construction, thereby causing problems at the end of the design work. According to Thyssen et al., 2010, if briefings from the client were misunderstood in green building design process it will lead to little appreciation by the client or multiple modifications of the design plan throughout the processes of the project, and that will bring additional expenses, conflicts and even unwanted legal terms between the parties of the contract. Many stakeholders provide insufficient information in the briefing phase of the design, hence, results in an insufficient project meaning, also bringing about a misunderstanding of the whole project by the architect. Therefore, architects should make sure that the clients' briefings are interpreted correctly during any kind of construction process. This problem can be solved through careful observation, hypothesizing, modelling and verification of the client's briefings (Smith et al., 1998).

Table 3: Comparison between Green Building Features and Users Need (Author, 2020)

\begin{tabular}{|c|c|c|}
\hline $\mathrm{S} / \mathrm{N}$ & Green Building Features & User Need (benefit) \\
\hline 1. & Uses less energy (energy efficient) & Saves cost on bills \\
\hline 2. & $\begin{array}{l}\text { Produces energy from renewable } \\
\text { sources }\end{array}$ & $\begin{array}{l}\text { Healthy to live using indoor plants for oxygen } \\
\text { supply }\end{array}$ \\
\hline 3. & $\begin{array}{l}\text { Light and oxygen production indoor } \\
\text { environment }\end{array}$ & Natural lighting and ventilation \\
\hline 4. & $\begin{array}{l}\text { Construction using cheap local } \\
\text { materials }\end{array}$ & $\begin{array}{l}\text { Reduces construction cost by avoiding exported } \\
\text { expensive materials }\end{array}$ \\
\hline 5. & Less waste generation & Less waste management efforts \\
\hline 6. & $\begin{array}{l}\text { Environmental friendly and } \\
\text { sustainable }\end{array}$ & Easily attain sustainable goals by the users. \\
\hline
\end{tabular}

\subsection{Green Building}

From the word 'green' literally denotes buildings constructed with clear intentions of using natural elements of Environmentally Sustainable Design (ESD) and ethics (Leaman et al., 2007). Green building means an energy-efficient building that produces minimal waste or reuses the waste products, harvest rainwater, generates energy sources from the surrounding physical elements and making human life sustainable by producing less harmful greenhouse gasses to achieve sustainable goals (Komolafe et al., 2016). Renewable energy can be gotten from the sun (solar energy), water stream (hydro-energy), wind, excreta and other organic waste produce (biogas or biodiesel) from the house like kitchen waste, human faeces, and plant seed called Jatropha Curcas which is usually used 
in fencing houses and farms in Kano state (Muktar et al., 2020). All these technological knowledge, when applied to architecture, will help reduce the cost of maintaining a building, and will also help reduce the pressure exerted in public water and energy supply. Speaking of the architectural design in a green building means the application of enough openings, carbon sensors and energy saving materials to enhance the building performance. However the use of cheap local materials in the constructions period helps reduce the construction cost of the overall building expenses, this technically means depending on the exported construction materials is not sustainable. Though, these materials have to be environmentally friendly to achieve the sustainability aim (Baba et al., 2015; Dahiru et al., 2018; Olotuah et al., 2018).

Greeneries like a potted flower, however, trees and garden around the building are also advisable for a healthy supply of oxygen and absorption of carbon dioxide exhaled by the users in green building. However, pot flowers can be placed within indoors or outdoors which become very essential especially during winter when all the windows are closed to warm the indoor environment and there is less concentration of oxygen and high concentration of carbon dioxide within indoors. Also, the placement of carbon sensor can help alert the inhabitants when the concentration of carbon dioxide is relatively high within indoors.

\subsection{Green Energy Efficient Buildings in Relation to Users Need}

The control of temperature within buildings is mainly influenced by conservation of energy, while the inhabitants' needs and well-being is also an essential factor to be considered, looking at the effects it has on their health and productivity. Nevertheless, users' demand and energy efficiency happen to be two factors opposing each other, which multi-objective optimization approach is applied to solve this problem. This model was conducted and resulted in a range of ideas on the optimization possibility to reduce the consumption of energy by $10 \%$ whereas giving the required comfort to the users (Martell et al., 2019). Using the multi-objective framework, many objectives of comfort were devised such as; energy efficiency, visual and thermal discomfort bearing in mind their cost and purpose which both of them are autonomous of each other and has to be reduced to the minimal level.

\subsection{Users Perception of Green Building}

According to Sant'Anna et al., 2018 users perceive green buildings environment to be enhanced in contrast with conventional buildings, though, guests might not experience much differences among them. This shows that users of green building have good remarks to it. In Kano State, Nigeria where the power shortage is very high, most of the green building users have the best experience. This is because of the alternative power supply from solar panels, rain harvest, well or borehole water supply, ventilation and natural lighting and many other features. Green buildings which were operated and designed appropriately tend to be user-responsive and attain good environmental results and concurrently bring good remarks based on and productivity comfort by the users. Apparently, green buildings that were not planned well with the users, due to either inadequate comprehension of the green design intention or less consideration of the user's needs, runs the risks of total user displeasure when compared with other conventional 
buildings.

\subsection{Demand of Green Building}

A study carried out by Robinson et al., 2016, demands for office green building features were analyzed between tenants in offices around the United States. Using the online internet survey, a sample of tenants were randomly collected in about 17 U.S. markets in which the majority were officers. The respondents provide their viewpoint about green buildings and show Willingness to Pay or Purchase (WTPP) green office building due to the benefits attached to it. The highest WTPP was recorded regarding indoor air quality improved and natural lighting. Results reveal that energy and IT industries and companies were almost certainly to pay or purchase buildings that are rated as green or energy-saving. Preferences in the demographic and regional are reflected in WTPP and feature ranking. Findings of the Robinson et al., 2016 study will deliver a platform for policymakers and stakeholders to develop green buildings with features that were regarded as very significant practices for green building, and determine how the demand of green features possibly varies around the globe. However, green building demand is also increasing in Nigeria, as people tend to understand the mechanism behind it and the fact that the Nigerian government failed to provide sufficient energy supply to the public. Likewise, the renewable energy market in Kano also keeps increasing as people losses hope on the public energy supply they tend to provide alternative sources for themselves. The same also goes to the public water supply which was not seen for decades in some part of Kano city, therefore, domestic users tend to be more attracted to buildings with boreholes, energy-saving appliances, renewable sources of energy such as solar panels and water heaters, wind turbines, biogas and biodiesel etc.

\subsection{Criteria used in Design Green Building}

The selection of low energy processing materials during construction and application of eco-friendly materials helps achieve a good green building construction. Most of the criteria used here are listed below:

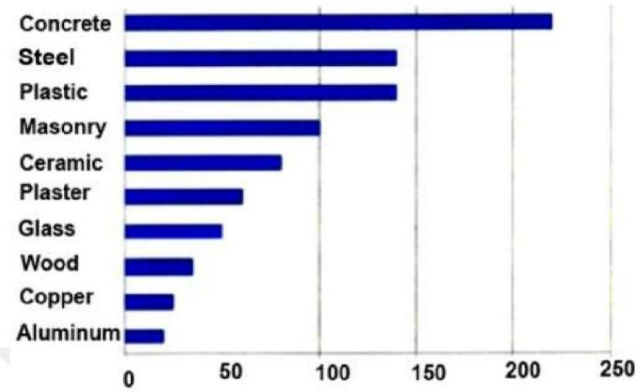

Fig.4: Embodied energy of some building materials (Tudora, 2011).

Here, the figure above shows the energy required to process some building materials during the construction process. Concrete carries a higher percentage, while Aluminium carries the lowest. This means that the energy required in making cement, starting from the limestone wining, transportation, crushing and pulverizing, screening, packaging up to the point of putting the cement in construction processes is very high, it may require higher 
fossil fuels as well, which in-return produce high amount to toxic gasses to the sky, thereby causing global warming. This criteria in the selection of material to be used during the construction process will enable the process of green construction to be sustainable. Likewise, Building Research Establishment Environmental Assessment Methodology (BREEAM) and Leadership in Energy and Environmental Design (LEED) were also used in assessing green buildings around the world.

\section{Case Study of Green Building in Kano State}

Though there minimal literature and number of green buildings in Kano state, a building located in Gwale Local Government Area had some of the green building features. This building is located in a neighbourhood called Yan-Alawa quarters with the GPS coordinates listed in the table below showing the four pegs (see table 4 \& fig. 5) in the rectangular shape of the green building.

Table 4: Coordinate Table of the Green Buildings' Location (Google Earth, 2020)

\begin{tabular}{|c|c|c|}
\hline S/N & Peg & Coordinates \\
\hline 1. & A & $11^{\circ} 59^{\prime} 12.31^{\prime \prime}, 8^{\circ} 30^{\prime} 22.24^{\prime \prime} \mathrm{E}$ \\
\hline 2. & B & $11^{\circ} 59^{\prime} 12.45^{\prime \prime} \mathrm{N}, 8^{\circ} 30^{\prime} 22.55^{\prime \prime} \mathrm{E}$ \\
\hline 3. & C & $11^{\circ} 59^{\prime} 11.74^{\prime \prime} \mathrm{N}, 8^{\circ} 30^{\prime} 22.85^{\prime \prime} \mathrm{E}$ \\
\hline 4. & $\mathrm{D}$ & $11^{\circ} 59^{\prime} 11.61^{\prime \prime} \mathrm{N}, 8^{\circ} 30^{\prime} 22.34^{\prime \prime} \mathrm{E}$ \\
\hline
\end{tabular}

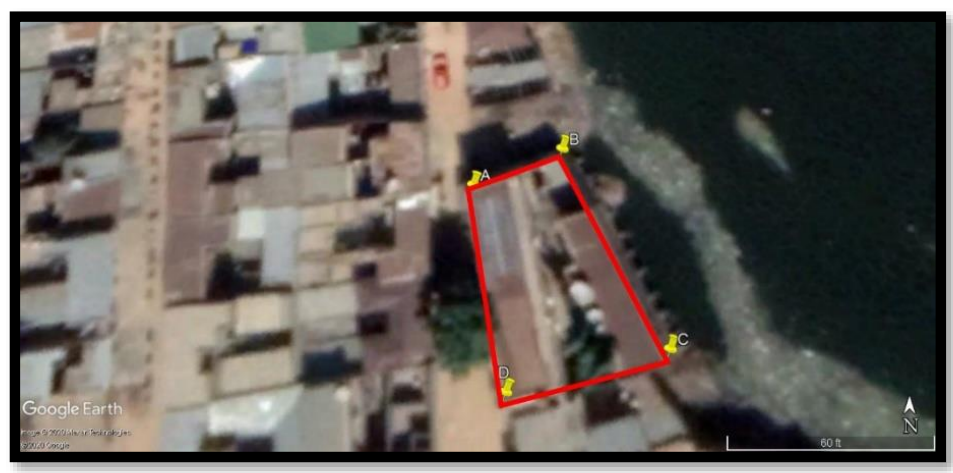

Fig. 5: Map View of the Green Building (Google Earth, 2020 earth.google.com/web/).

The coordinates shown in table 4 were those indicated in the rectangular box in fig.5, the map was aligned to the north and the scale was zoom to $60 \mathrm{ft}$ per centimetre equivalent to 18.29 meters per centimetre. The presence of a pond by the eastern part of the building, and an access road by the west where the house is facing. The house has access to public electric supply which goes off unannounced and unreliable, while water pipes were also connected to the main public supply pipes but it has been years since water is seen in this region. The southern part of the house is linked to a neighbouring house with only one wall, though there is absolute security and privacy since there is no access door linking the two. From the northern part of the house in fig. 5 is parcel of land which is fenced with corrugated zinc wall. The two types of wind in Nigeria are north-east trade wind and 
southwest monsoon wind, northeast wind usual comes with cold, dry and dust, while southwest wind comes with heat, high humidity and rain. The house is structured to receive both winds at both the two directions, having cross-ventilation within indoors.

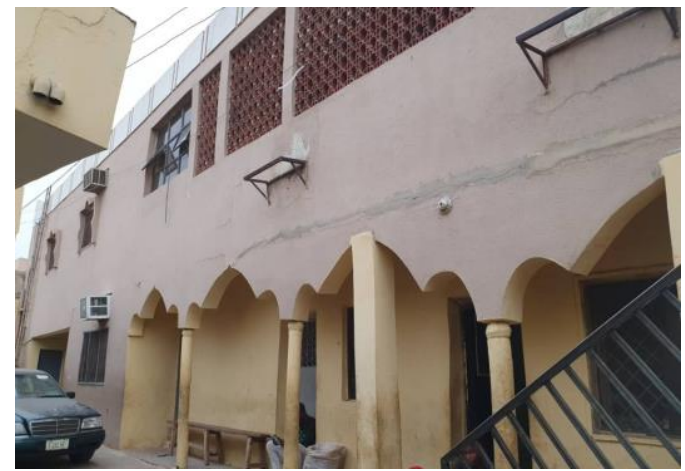

Fig. 6 Showing the arrangement of windows and solar shading red bricks in the green building (Field Survey, 2020).

The overhead water tanks that supply water to the building using gravitation force were placed at the rooftop of this building and a metallic ladder leading to them by the extreme left side of fig.6. These tanks were filled with water using the electric borehole water supply, powered either by solar energy or public electric supply. However, the courtyard also serves many purposes in the house, these include protection, security, circulation of cool air into the rooms, playground for children, car park, relaxation area and privacy. This part of the house can receive northeast wind during the dry season.

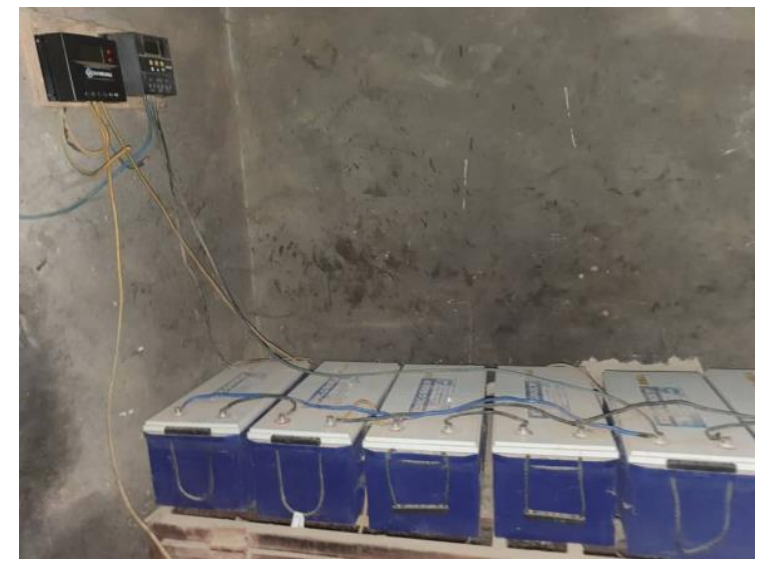

Fig. 7: The solar system installed in the green building (Field Survey, 2020).

Here in fig. 7 the solar panels were placed at the rooftop of the building which is used to charge these 24 batteries. This solar system can serve the building for about 24 hours duration, however, a non-energy saving appliance like electric heaters was not put to use whenever the solar system is serving the building with electricity. 


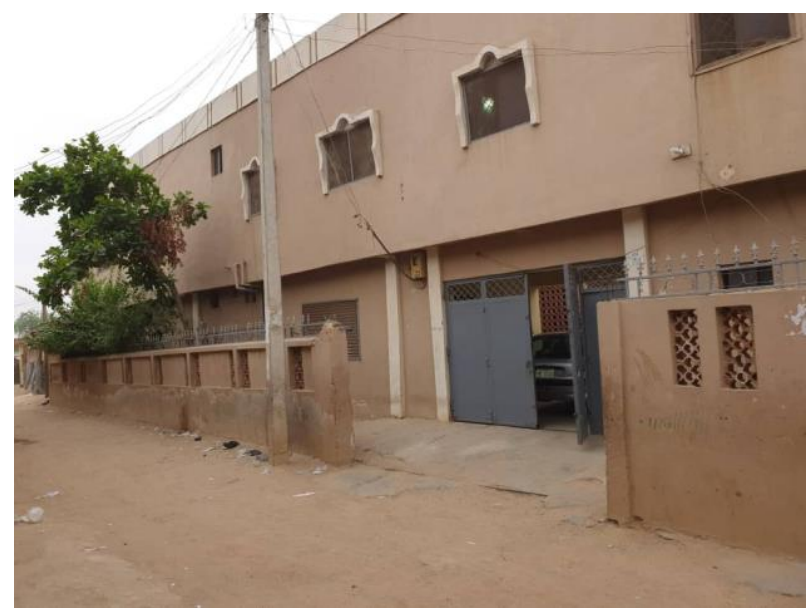

Fig. 8: Showing the façade of the house (Field Survey, 2020).

Fig. 8 shows the façade with some trees that reduces the impact of the sun and wind in some part of the building, however, the windows have nets to minimise insects flooding over the rooms. This part of the building can receive southwest wind during the rainy season.

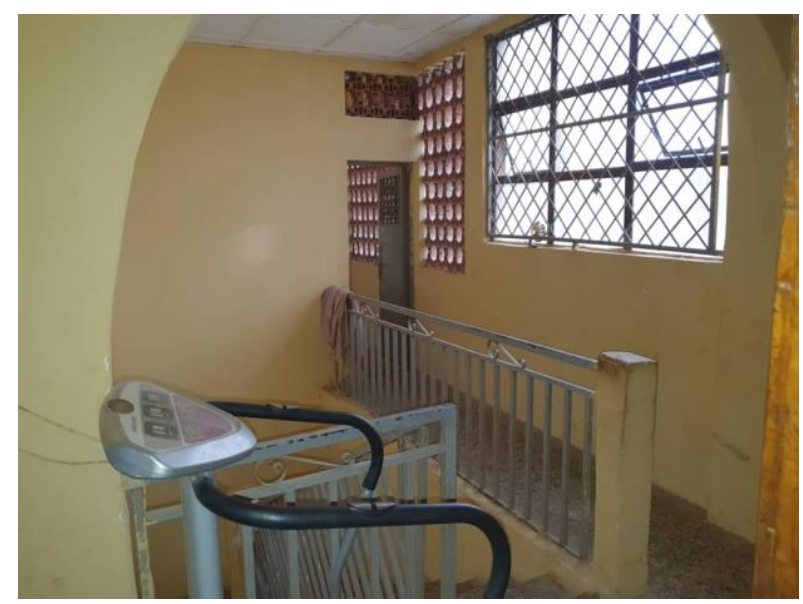

Fig. 9: Showing the interior staircase having enough lighting (Field Survey, 2020).

Natural lighting during the day is an essential part of green building as shown in fig. 9, the light is enough to the surrounding during the day, with the help of an extra-large window here. Therefore, the staircase can fully be functional without extra energy to make it visible during the broad daylight. 


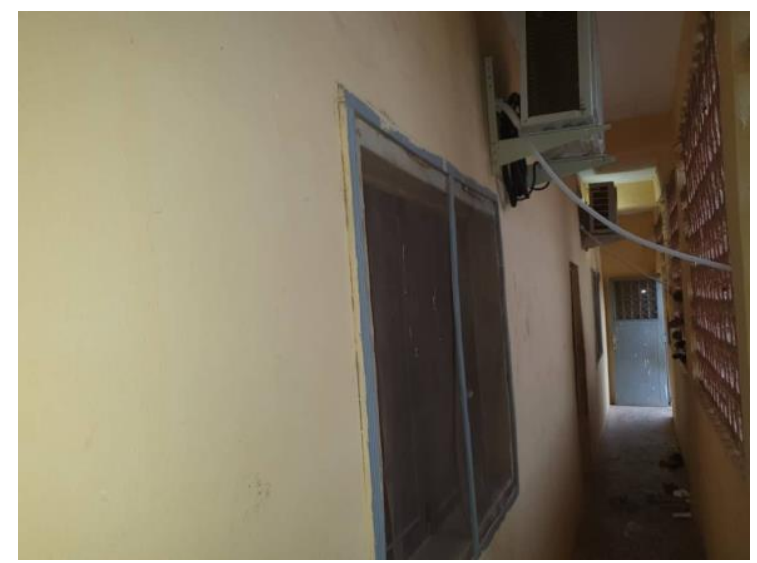

Fig.10: Showing the corridor, the Inverter Air Conditioner, the solar shading bricks, windows and enough lighting during the day (Field Survey, 2020).

Inverter Air Conditioner: Inverter is an electronic device that converts current frequency. This equipment was installed in numerous domestic electronic appliances including air conditioners (as shown in fig. 10), which regulates electric voltage, frequency and current. While an Inverter Air Conditioner regulates the compressor's speed making the refrigerant (gas) flow rate controlled so that the device consumes minimal electric current and energy.

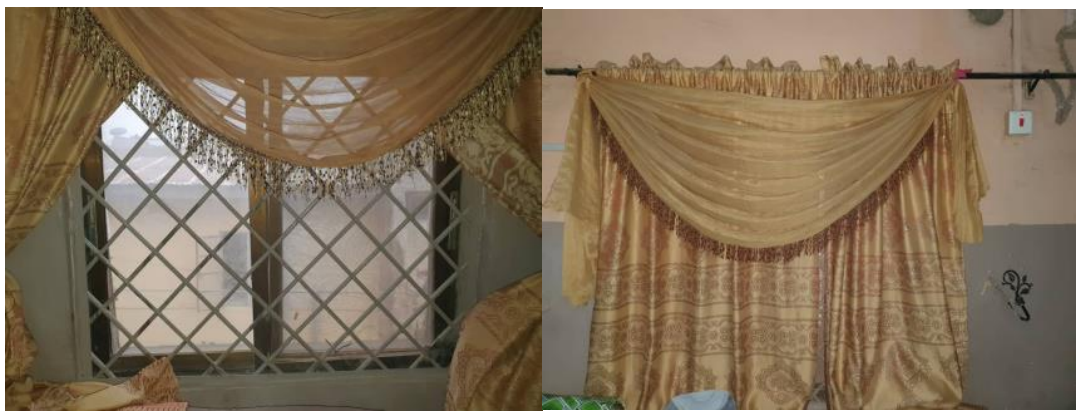

Fig. 11: Cross ventilation/light within the rooms Fig. 12: Elaborating the control of light using thick curtain Source: Field Survey, 2020

Fig. 11 and 12 shows the presence of cross-ventilation within indoors, control of natural light, privacy and security bars present in this building, however insects are also regulated with a net covering the window.

The features of this green building were listed below:

a. The use of solar power to generate electricity and energy-saving appliances within the building,

b. The provision of a borehole water source to an overhead tank, which flows through the pipe to the kitchen and toilets within the house,

c. The presence of cross-ventilation and adequate lighting within indoors,

d. Incorporated with greeneries in the compound for oxygen production, 
e. The placement of sun-shading bricks from the east side of the building to avoid early morning sun rays,

f. Construction of underground tank for rainwater harvest and,

g. Availability of waste management and treatment pit for latrine and kitchen wastewater. With the problem of light and public water supply within the urban centre of Kano accompanied with high problems of street sanitation and improper waste management system, the building was able to provide all the necessities closer to the surrounding.

\subsection{The Perception of the Users Living in the Green Building.}

The building was situated close to a pond which makes cool breeze came into the house during hot weather, therefore there was good remark is that direction, though, during cold weather it tends to be extremely cold within indoors, making it inhabitable to cope without heat source within the rooms. The cold season is short usually for 3-4 months, while hot weather comes in two forms in this region; hot dry and hot humid/wet season. However, the providing of alternative power supply and the use of energy-saving appliances reduces the public electric bills paid monthly. However, the absence or unreliable public water supply through the pipes makes the borehole a necessary aid in making life comfortable when the water need arises for domestic use in the building. Another problem faced within the house is mosquito-spread from the nearby pond and noise generated from the neighbourhood, though the window nets were provided to reduce the spread of the mosquito and other insects within the building. Also, two types of curtains were used in the building which helps in controlling light and sound absorbance within indoors. The two types of curtains were thick and thin transparent curtains placed in every opening of every room (i.e. doors and windows).

\section{Discussion}

It is remarkably clear that great user's satisfaction can be achieved using green energy-efficient techniques of the building process and building utilities. At the same time, this process simultaneously promotes sustainability and slows down the production of the harmful environmental process. With reference to the perception gotten from the users of the green building in Kano (the case study) were satisfactory. According to Ornetzeder et al., 2016 reported the results of user satisfaction in an ultra-low energy-saving building, which indicated a high level of users satisfaction in office buildings with about $84 \%$. This also goes in accordance with the findings of this research, due to significant of the use of energy-saving appliances in the case study used in this research. These appliances starting from a bulb, fan, air conditioners, television and so many others were carefully selected and rated as energy-saving before used. This enhances the energy condition within such building, and promote the environment-friendly practice in green building. However, Ornetzeder et al., 2016 continued with the discussion of his findings, stating that many green users of official buildings were satisfied sufficiently with their respective indoor air quality and temperatures. Though, most the users indicate less satisfaction with some features within the green building like the break-out spaces. It is significant since on the other side the demonstration of the findings a strong correlation among the satisfaction entirely and the convenience of the break-out spaces. Nevertheless, floor-spacing per each 
individual within the building powerfully affects the use of energy in energy-saving buildings. However, somehow, energy-efficient processes in buildings can surely link to minimal user's satisfaction around the house.

\section{Conclusion}

As stated in this research, users' need or satisfaction and energy efficiency are two opposite phenomenon which can be balanced using the concept of green building and multiobjective approach. The best approach to sustainability is by the provision of green buildings within individual households, to minimize the hazard caused by our conventional buildings to the planet at the same time making the users around it comfortable. The fact that green may not satisfy the user $100 \%$ so also the conventional buildings cannot be absolutely satisfactory to its users. However, a great percentage of user's satisfaction was recorded in green building through the case study presented and also with the help of a green building rating system (BREEAM and LEED). Therefore, green building can satisfy users to meet up with their basic needs in housing provision, add value the facility when intended to sell, and also save our dying planet from the toxins produced by the conventional buildings. Although, when the temperature was too cold or too hot, the satisfaction of green users was found to be low, yet saving cost and sustainable nature of the green building makes it unique and marketable to the buyers. The study also reveals how green building demand is increasing around the world, likewise in Kano green building is increasingly getting attention due to failure of the government to provide sufficient public utilities, such as portable water and electric supply in Kano. It is therefore concluded that green building users enjoy many benefits by using the energy-efficient building. These benefits might be in terms of saving cost, healthy living within indoors, access to electricity and water for domestic use and so on.

\section{Reference}

Ahmadi-Karvigh, S., Becerik-Gerber, B., \& Soibelman, L. (2019). Intelligent adaptive Automation: A framework for an activity-driven and user-centered building automation. Energy and Buildings, 188189, 184-199. https://doi.org/10.1016/j.enbuild.2019.02.007

Baba, A. N., Achoba, M. I., \& Otaro, O. T. (2015). Evaluating the Prospects and Challenges of Sustainable Housing on National Development in Nigeria. Nternational Journal of Scientific Research in Science, Engineering and Technology, Themed Section: Science and Technology, 1(5), 435-441.

Bansal, P., \& Hunter, T. (2003). Strategic explanations for the early adoption of ISO 14001. Journal of Business Ethics, 46(3), 289-299.

Berg, F., Flyen, A. C., Godbolt, Å. L., \& Broström, T. (2017). User-driven energy efficiency in historic buildings: A review. Journal of Cultural Heritage, 28, 188-195. https://doi.org/10.1016/j.culher.2017.05.009

Brown, Z., Cole, R. J., Robinson, J., \& Dowlatabadi, H. (2010). Evaluating user experience in green buildings in relation to workplace culture and context. Facilities, 28(3-4), 225-238. https://doi.org/10.1108/02632771011023168

Carlucci, S., Causone, F., De Rosa, F., \& Pagliano, L. (2015). A review of indices for assessing visual comfort with a view to their use in optimization processes to support building integrated design. Renewable and Sustainable Energy Reviews, 47(7491), 1016-1033. https://doi.org/10.1016/j.rser.2015.03.062

Connelly, J., \& Smith, G. (2012). Politics and the environment: From theory to practice. Hoboken: Taylor and Francis. 
Consoli, D., Marin, G., Marzucchi, A., \& Vona, F. (2016). Do green jobs differ from non-green jobs in terms of skills and human capital?. Research Policy, 45, 1046-1060.

Dahiru, D., Dania, A. A., \& Adejoh, A. (2018). An Investigation into the Prospects of Green Building Practice in Nigeria An Investigation into the Prospects of Green Building Practice in. Journal of Sustainable Development, 7(6), 158-167. https://doi.org/10.5539/jsd.v7n6p158

Darses, F., \& Wolff, M. (2006). How do designers represent to themselves the users' needs? Applied Ergonomics, 37(6), 757-764. https://doi.org/10.1016/j.apergo.2005.11.004

Dubois, C. L. Z., \& Dubois, D. A. (2012). Strategic HRM as social design for environmental sustainability in organization. Human Resource Management, 51(3), 799-826.

Earth, G. (2020). Google Earth, US Department of State Geographer, Data: SIO, U.S, Navy, NOAA, GEBCO. IMAGE: Landsat/Copernicus (Areal View of the Case Study in Kano). Retrieved from earth.google.com/web/

Ehnert, I. (2009). Sustainable human resource management: A conceptual and exploratory analysis from a paradox perspective. Berlin: Physica-Verlag.

Festus, I. A., \& Amos, I. O. (2015). Housing Policy in Nigeria : An Overview. American International Journal of Contemporary Research Housing, 5(2), 53-59. Retrieved from http://www.aijcrnet.com/journals/Vol_5_No_2_April_2015/8.pdf

Guerci, M., \& Carollo, L. (2016). A paradox view on green human resource management: Insights from the Italian context. International Journal of Human Resource Management, 27(2), 212-238.

Ibacache, K. (2020). Building Collections through Purchase Suggestions in Academic Libraries. Collection Management, 45(2), 179-192. https://doi.org/10.1080/01462679.2019.1666332

Iloeje, N. P. (2001). A new geography of Nigeria. Longman Nigeria PLC. (new revise).

Jabbour, C. J. C., \& Jabbour, A. B. L. D. S. (2016). Green human resource management and green supply chain management: Linking two emerging agendas. Journal of Cleaner Production, 112, 1824-1833.

Jabbour, C. J. C., \& Santos, F. C. S. A. (2010). Relationships between human resource dimensions and environmental management in companies: Proposal of a model. Journal of Cleaner Production, 16, 51 58.

Kabir, O. K. (2004). Low-cost Technology and Mass Housing System in the Nigerian Housing. Journal of Applied Sciences, Vol. 4, pp. 565-567. https://doi.org/10.3923/jas.2004.565.567

Kaya, S. (2004). Relating building attributes to end user's needs: "the owners-designers-end users" equation. Facilities, 22(9), 247-252. https://doi.org/10.1108/02632770410555968

Khorram, M., Faria, P., Abrishambaf, O., \& Vale, Z. (2019). Air conditioner consumption optimization in an office building considering user comfort. Energy Reports, 6, 120-126. https://doi.org/10.1016/j.egyr.2019.08.029

Komolafe, M. O., Oyewole, M. O., \& Kolawole, J. T. (2016). Extent of incorporation of green features in office properties in Lagos , Nigeria. Emerald Insight, 5(3), 232-260. https://doi.org/10.1108/SASBE08-2015-0019

Leaman, A., \& Bordass, B. (2007). Are users more tolerant of "green" buildings? Building Research and Information, 35(6), 662-673. https://doi.org/10.1080/09613210701529518

Leaman, A., Thomas, L., \& Vandenberg, M. (2007). 'GREEN' BUILDINGS : (November).

Lee, J. H., Cho, H., \& Kim, Y.-S. (2016). Users’ Music Information Needs and Behaviors: Design Implications for Music Information Retrieval Systems Jin. Journal of the American Society for Information Science and Technology, 64(July), 1301-1330. https://doi.org/10.1002/asi

Li, J., Huang, J., Liu, Z., \& Cai, Z. (2011). The effects of employee training on the relationship between environmental attitude and firms' performance in sustainable development. International Journal of Human Resource Management, 23(14), 1-14.

Lourenço, P., Pinheiro, M. D., \& Heitor, T. (2019). Light use patterns in Portuguese school buildings: User comfort perception, behaviour and impacts on energy consumption. Journal of Cleaner Production, 228, 990-1010. https://doi.org/10.1016/j.jclepro.2019.04.144

Mansour, O. E., \& Radford, S. K. (2014). Green Building Perception Matrix , A Theoretical Framework. 16th Annual Architectural Research Symposium, Finland, (March), 40-52.

Martell, M., Rodríguez, F., Castilla, M., \& Berenguel, M. (2019). Multiobjective control architecture to estimate optimal set points for user comfort and energy saving in buildings. IS A Transactions, (xxxx). https://doi.org/10.1016/j.isatra.2019.10.006 
Mortimore, M. (1989). Adapting to drought: Farmers, famines and desertification in West Africa. Cambridge: Cambridge University Press.

O'Donohue, W., \& Torugsa, N. A. (2016). The moderating effect of Green HRM on the association between proactive environmental management and financial performance in small firms. International Journal of Human Resource Management, 27(2), 239-261.

Olotuah, A. O., Olotuah, A. A., Olotuah, A. M., \& Adedeji, Y. M. (2018). International journal of engineering sciences \& research technology ecological approach to sustainable housing development in nigeria. 7(12), 281-285.

Ornetzeder, M., Wicher, M., \& Suschek-Berger, J. (2016). User satisfaction and well-being in energy efficient office buildings: Evidence from cutting-edge projects in Austria. Energy and Buildings, 118, 18-26. https://doi.org/10.1016/j.enbuild.2016.02.036

Paillé, P., Chen, Y., Boiral, O., \& Jin, J. (2014). The impact of human resource management on environmental performance: An employee-level study. Journal of Business Ethics, 121, 451-466.

Reim, M., Körner, W., Chhugani, B., \& Weismann, S. (2017). Correlation between energy efficiency in buildings and comfort of the users. Energy Procedia, 122, 457-462. https://doi.org/10.1016/j.egypro.2017.07.291

Renwick, D. W. S., Redman, T., \& Maguire, S. (2013). Green human resource management: A review and research agenda. International Journal of Management Reviews, 15, 1-14.

Robinson, S., Simons, R., Lee, E., \& Kern, A. (2016). Demand for Green Buildings: Office Tenants' Stated Willingness-to-Pay for Green Features. Journal of Real Estate Research, 38(3), 423-452.

Sant'Anna, D. O., Dos Santos, P. H., Vianna, N. S., \& Romero, M. A. (2018). Indoor environmental quality perception and users' satisfaction of conventional and green buildings in Brazil. Sustainable Cities and Society, 43(July), 95-110. https://doi.org/10.1016/j.scs.2018.08.027

Smith, J. M., Kenley, R., \& Wyatt, R. (1998). Evaluating the client briefing problem: An exploratory study. Engineering, Construction and Arcbitectural Management, 5(4), 387-398. https://doi.org/10.1108/eb021091

Sotunde, O. (2014). FCMB CAPITAL INVESTS \$65M IN NIGERIA'S FIRST GREEN BUILDING. Retrieved from Business website: http://venturesafrica.com/fcmb-capital-invests-65m-in-nigeriasfirst-green-building/

Subramanian, N., Abdulrahman, M. D., Wu, L., \& Nath, P. (2016). Green competence framework: Evidence from China. International Journal of Human Resource Management, 27(2), 151-172.

Taylor, S., Osland, J., \& Egri, C. (2012). Introduction to HRM's role in sustainability: Systems, strategies, and practices. Human Resource Management, 51, 789-798.

Thyssen, M. H., Emmitt, S., Bonke, S., \& Kirk-Christoffersen, A. (2010). Facilitating client value creation in the conceptual design phase of construction projects: A workshop approach. Architectural Engineering and Design Management, 6(1), 18-30. https://doi.org/10.3763/aedm.2008.0095

Tudora, A. C. (2011). Assessments Criteria of Building Materials from Ecological Point of View. Buletinul Institutului Politehnic Din Lasi. Sectia Constructii, Arbitectura, 57(4), 129.

Wehrmeyer, W. (Ed. . (1996). Greening people: Human resources and environmental management. Sheffield: Greenleaf.

WGBC. (2007). World Green Building Council "WORLDGBC NEED." Retrieved June 3, 2007, from www.worldgbc.org

WorldGBC. (2020). About Green Building. Retrieved from World Green Building Councils website: https://www.worldgbc.org/what-green-building 